\title{
PAUL, HERMENEUTICS AND CHARACTER: IMPLICATIONS FOR SCRIPTURE AND IDENTITY ${ }^{1}$
}

\author{
Jeremy Punt \\ University of Fort Hare
}

\begin{abstract}
The Bible as foundational document and as important source of identity in the Christian tradition and its religious communities, and its contribution to the formation of the identity of certain forms of culture and literature, is considered from the perspective of "enscripturalised identity". The point of departure is the Pauline perspective on identity, which is introduced against the broader context of notions of identity in the first century CE. From Paul's insistence on the new identity of the followers of Christ, the focus is turned to how his insistence upon a new hermeneutic characterised by freedom correlates with the new identity in Christ, resulting in an embodied hermeneutic and a self-understanding developed from Scripture. In a second part of the study, enscripturalised identity is considered with regard to contemporary, multicultural South Africa, amidst the attempt to forge a sense of common vision and character. Affirming the close links between religion and notions of identity, the particular value of the relationship between Scripture and identity in Africa is considered. It is concluded that notions of identity advocated by Paul should be understood in reciprocal relationship to his foundational scriptures, and that enscripturalised identity will be ignored at peril when reflecting on the general character of the South African rainbow nation.
\end{abstract}

\section{Introducing enscripturalised identity}

[M] uch of identity, Jewish and Christian alike, is bound up in this interpretive debate over Paul (Matlock 1998:449; emphasis in the original).

Enscripturalised identity is not an essentialist notion, claiming or establishing an absolute identity, legitimated by biblical proof texts, but is suggested as a heuristic device for investigating Scripture's contribution to the hybridity or hyphenated nature of identity (cf Walters, Martin and Cochrane 1999:81-83), primarily in Christian communities but also its role in broader socio-religious patterns and constellations, ${ }^{2}$ local and global. "This is, in fact, one of the major functions of religious literature, whether that literature is the Christian Bible, the Jewish Tanakh, the Islamic Qur'ân, or the Hindu Upanishads. All of these literatures contain stories that tell the reader what the world is like, what constitutes good and evil, and what it takes to be a good and ethical person" (Haas 1996:186). The social construction of cultural, national and ethnic identities - which are "not god-given or natural artefacts" (Said 1991:11) — is taken serious when entertaining the notion that Scripture has played a role in and contributed to identity, in early times as well as in South Africa today.

With enscripturalised identity, then, is not meant inscribed identity, or narrative identity, a

1. An edited section of a paper, "Paul, freedom and character: Scripture and identity in South Africa", read at the annual AAR/SBL meeting in Boston, MA, 20-23 November 1999.

2. Cf Beyer (1994:226-227) on "the search for self-description" within a global society where religious culture on global scale still allows for "subglobal and particular systemic religion and religious culture". 
palpability of personality or individuality. Depending on what is meant by these concepts, enscripturalised identity may include such notions but goes beyond that to the involvement of language and literature in the construction of reality. More particularly, in this study identity is about the socio-cultural formation of groups of people, and is primarily related to the dynamics that obtain in the interrelation of socio-cultural formation and sacred texts in general, and the Bible (here, the New Testament) in particular.

However, enscripturalised identity is only as ambiguous as it is inevitable in Christian communities and societies wherein such communities have a measure of influence. It is common knowledge that the same Bible has been used to declare war and to proclaim peace, to justify oppression and to support struggles for human freedom, to legitimate human excesses and to provide the stimulus for human development. It is becoming common to acknowledge - if not always to investigate - how prominent the Bible has been in its presence in political, economical, sexual, cultural and other areas of human thought, especially in the Western world and there where the West made its presence felt.

In this paper Pauline perspectives on identity will be investigated in relation to their embeddedness in first century scriptural communities, but the focus will be on the relationship between hermeneutics and identity in Pauline thought, rather than on what properly constitutes the content of "Christian" identity according to Paul. In a second and shorter section, and with the foregoing discussion in mind, the place of enscripturalised identity in South Africa's Christian communities will be evaluated briefly. ${ }^{3}$

\section{Paul, community, Scripture and first-century identity ${ }^{4}$}

His constant appeals to the communities are not clever rhetorical tricks; they are his understanding of the deepest urge within us for identity. In identifying Jesus, Paul also identifies us (Fischer 1996:66).

Even if it is true that, as Fischer argues, apart from everything else one might want to add, early Christianity "gave identity to a people" (1996:68), ${ }^{5}$ it might at first sight sound strange to include Paul in a discussion of identity, at least if it concerns a particular identity. Paul, it should be remembered, prided himself on being all things to all people (1 Cor 9:22), an

3. Space disallows discussion of other related matters, e g how people (Christians) today are influenced by and develop enscripturalised identity (as for example through sermons, liturgy, religious literature, Bible study activities, etc. Cf e g homiletic studies on biblical preaching which essentially offers a new image or language world, Achtemeier (1980:22-30); discussion of the nature of religious discourse and language qua discourse and language (e g Stiver 1996); the relationship between language and the perception of reality, or between literacy and social organisation (e g Stock 1983:88-240); or the debate on whether the "word" or the "text" has primacy (cf respectively e g Smith 1997:61 n44 and Lindbeck 1989:95 n9).

4. Again, the emphasis in this study is not to compile a comprehensive description of Christian identity à la Paul, which is fraught with difficulties. Furthermore, I would insist that such an endeavour will in any case run contrary to Pauline hermeneutical style, which is not essentialist and prescriptive but dynamic and participatory. Although it might be useful to establish some parameters of our construction of Christian identity informed by the Pauline letters, my emphasis will rather be on Paul's use of Scripture in formulating the social identity of the early believers in Christ, and to establish what one might gain from his hermeneutical endeavours.

5. He adds that it is not surprising, as this is what "great mythic stories" always accomplish; with detrimental effects to the myths of the surrounding cultures. "It did not destroy mythology; it replaced it with one which was paradoxically both more transcendent and more practical" (Fischer 1996:68). Whether the Christian "myth" destroyed those of the cultures where Christianity was established or incorporated them into its own myth — and whether the latter would necessarily imply their destruction — will not be debated here. 
explicit claim regardless of his ability to do it justice. Would it be fair to yoke someone expressing such a clear intercultural identity, into the discussion of Christian identity? Or could it be that his preference for intercultural and "religious" identity is exactly where the advantage of entering into dialogue with Pauline perspectives on identity becomes valuable? On the other hand, of all the documents making up the Bible, the Pauline letters arguably have had the greatest influence in the shaping of Christian theology, morality and consciousness and can hardly be ignored when discussing Christian identity. And conversely, the current scholarly debate on the interpretation of Paul is to a large extent defined by issues of identity, as will emerge below. This can already be seen when an attempt is made to understand Paul in his time, trying to look at Paul in the light of first-century concerns about identity.

\subsection{Paul amid early first-century CE identity}

[Paul's discourse on the Law and Judaism is] forever caught in a paradox of identity and difference (Boyarin 1994:204; cf Matlock 1998:450).

A discussion of identity in the Pauline letters from the perspective of enscripturalisation has to be situated in amidst first-century notions of identity. Recent years have witnessed a gradual acceptance of the pluriformity of Jewish life during the time of the New Testament. There is no reason to doubt Bij de Vaate and Van Henten's claim (1996:27-28) that scholars have become increasingly aware of the diversity of Jewish life in Palestine and in Diaspora during the Hellenistic and Roman period. ${ }^{6}$ Similarly, Murray (1982:196,201-202) holds that the supposed distinction between Hellenistic and Palestinian Judaism as separate entities in themselves is patently false, given the pervasive influence of Hellenism ${ }^{7}$ even within Palestine. This would mean that the notion of Hellenistic Judaism is not an oxymoron at all then again, neither is it a tautology.

The boundaries between "Hellenism" and "Judaism" as two different and separate entities have been eroded, especially because of two recent developments. The first is the increasing awareness of the falseness of postulating a "rationally superior out-going Greek or 'Western' culture and the justly submitting 'Oriental' cultures conquered by Alexander". This has led to research which shows the "initial insularity of the Greek conquerors in the conquered lands" and the consistent influence of Greek culture in the Mediterranean area long before Alexander's conquests. ${ }^{8}$ Secondly, "big, generalizing claims about Diaspora Judaism versus Palestinian Judaism" is no longer possible; similarities and differences need to be accounted for in a more cautious way (Engberg-Pedersen 1995b:xvxiv-xix).

The often harsh distinctions forced on different "categories", forms or strands of Judaism during the first century — as for example in Montefiore's work — have been questioned. This is especially true of the notion that Hellenistic and Palestinian Judaism were two quite

6. It has become widely accepted that it is not possible to think of first-century Judaism in monolithic terms. There simply was no authoritative or normative Judaism during that time: Judaism was a pluriform phenomenon. It is still common, though, to refer to different categories of Judaisms during the first century, i e rabbinic (or Palestinian), Hellenistic (or diaspora), and apocalyptic (cf e g Howell 1993:317). Cf also note 10 .

7. In the sense of "the mixed culture that developed in the various parts of the eastern Mediterranean area before, during and after the Hellenistic period proper", and thus distinct from the Hellenistic period of "political dominance" (cf Engberg-Pedersen 1995b:xviii n5).

8. Hellenistic culture is a term indicating "the culture that results from mixing originally Greek cultural elements with originally non-Greek cultural elements. It is the mixture (in a given time and place) that constitutes Hellenistic culture proper (in that place)" (Engberg-Pedersen 1995b:xvii-xviii; emphasis in original). 
different and even opposing movements (e g Davies 1980:1-16). The equally often presumed distinctions between Hellenistic and Palestinian Judaism are increasingly questioned, especially since the discovery of the Dead Sea Scrolls and continuing investigation of the early Jewish literature: Old Testament Pseudepigrapha, Apocrypha, Targums, Midrashim and Mishnaic traditions (Howell 1993:322). ${ }^{9}$

It means that the boundary lines between Jewish and non-Jewish identity appear to be less than rigid and even blurred (Bij de Vaate and Van Henten 1996:28). This realisation could lead to one of two conclusions, the more adequate of which is still in contention. Relaxed "border-control" in the first century would probably have initiated more cordial relationships between Jews and non-Jews, and such interaction could lead to one of two reactions, and some positions in between: mutual acceptance of Jewish and non-Jewish bona fides, or alternatively, a more determined effort — at least from the Jewish hard-liners — to reestablish social (and political) control by insistence on adequate lines of demarcation.

Some scholars, however, insist that the characteristic elements and claims of the firstcentury Jewish groups, on the one hand, and the in variety smaller but still different "Christian" groups, on the other hand, determined their relationship to a large extent. For example, in his attempt to uncover the identity rather than theology of Paul as it emerges from his letters, Volf (1996:43-50) argues for retaining the traditional (Baurian) view of the "universality of Christianity" versus the "exclusivism of Judaism" and sees Paul's shift initiated by the Damascus-road events as a move "from the bodiliness of genealogy to the pure spirituality of faith, from the particularity of 'peoplehood' to the universality of multiculturality, from the locality of land to the globality of the world". In this argument, Volf aligns himself closely with Boyarin, ${ }^{10}$ who in turn, finds his starting point in Dunn's thesis that Paul's polemic directed at the Law was an attempt to address Jewish nationalism and ethnocentrism which effectively excluded "Gentiles" from the covenantal relationship with God.

But the Baurian template of Christian universalism versus Jewish particularism is becoming more and more untenable, particularly when used to interpret the Pauline injunctions against the Law. Richard Horsley severely criticised any attempt to explain Pauline thought in terms of the dichotomy "Judaism" and "Christianity", which "more than any other modern construct ... determines the construction of 'Paul'".

Despite widespread admission of the anachronism involved (for both!), use of the constructs continues. However much the concepts may have been changing, the dichotomy, enshrined in standard studies and reference works in the field, still carries the connotations of Christian "universalism" and transcendent spirituality versus (a divinely rejected) Jewish particularism and legalism. Numerous recent studies have demonstrated that key aspects of these pretentious, all-encompassing constructs have no basis in Pauline and other literature, including the Book of Acts, which is of questionable validity as a historical source (Horsley 1995:1153).

Horsley argues that it is only in late Antiquity that one finds evidence for the "constructs" of "Judaism" and "Christianity" as used since the nineteenth century.

9. The supposed differences or even opposition between Palestinian and Hellenistic Judaism is questioned in light of recent research (cf e g Lieu, North and Rajak 1992:1-8; Murray 1982:194-208); however, Feldman (1986:83-111) argues that there was a distinction in the degree of Hellenisation between Jewish groups in diaspora and those in Palestine.

10. Boyarin, however, criticises the coercive "universalising" or multicultural transformation of the Jewish tradition (1994:228-260). 
In similar vein, Segal has recently written extensively on the relationship between Pauline and Jewish thought on universalism and particularism in the first-century Jewish-Hellenistic world $^{11}$ (1990; 1995:1-30). In explaining Pauline thought on the relationship Jew-Gentile, he argues from the perspective of the Jewish environment, and the different models of incorporating Gentiles into the Jewish tradition, ${ }^{12}$ in particular. Apart from a fully-fledged conversion to Judaism, ${ }^{13}$ two other models for Gentile inclusion, those of resident sojourner ${ }^{14}$ and Noachide commandments ${ }^{15}$ were available, though with different purposes and motivations.

The difference between the Noachide commandments and the rules for the sojourner is clear from a social point of view. The resident sojourner must, because of his close association with the Israelites, observe some laws of Judaism, while the Noachian commandments refer to the ultimate disposition of Gentiles and thus entirely to Gentiles who are not observant (Segal 1995:16).

The corresponding social situations would be, in the case of the sojourner Gentile, one where Jews are in the majority and have political power, and the other an opposite situation where the Noachian commandments were the model to accommodate righteous Gentiles. ${ }^{16}$

Paul, a Jew and from Pharisaic background at that, was faced with a situation where Gentiles were increasingly the majority within the church which included Jewish Christians, and was hard-pressed to avoid "two classes of Christians". Naturally, Paul addressed this issue from his own socio-religious framework: "Paul begs moderation and continues to argue that the Gentiles are to be added to the community of the faithful through the model of the

11. His arguments are in line with the increasing tendency to explain Paul's mission to the Gentiles, both in his own perception of it and in the presentation thereof, against the background of a revisioned Jewish pattern of universalism, rather than of the rejection of Jewish particularism (Donaldson 1994:166-193).

12. A basic distinction in first-century Judaism which Segal insists upon is the difference between conversion and salvation: the former entails the Law, the latter not necessarily as in the case of "righteous Gentiles" (1995:56; cf Boyarin 1994:299-300 n1). It also bears well reminding that first-century "Christianity" was in many ways related to other Jewish groups, although it should probably not be seen as a Jewish "sect" such as e g Pharisaism was (cf Meeks 1985:106). Cf in this regard also Goldenberg (1997:99-107) who concludes that through its internal diversity and notwithstanding Jewish acculturation in the Greco-Roman world, "in the long run the gentile world was marginal to the religious cosmos of virtually all Jews in antiquity". In the end, concludes Goldenberg, there was much more diversity in Jewish attitudes to Gentiles and their religious practices, including high levels of tolerance, than what is often acknowledged.

13. Or proselytism, which was something quite impossible in some hard-line Jewish groups where circumcision on the eight day was required, cf Jubilees 15:26-27 (Segal 1995:10-11). Conversion implied, of course, full observance of the Law, including circumcision (cf also Grabbe 1994:535-536). On the other hand, Donaldson proposes that the category of proselytism is probably the "place to begin" when Pauline mission and gospel is explained according to the revisioning of Jewish universalism (1994:193).

14. This model "derived from the biblical rules incumbent upon 'the stranger in your gates"'. Certain Jewish ceremonial and moral regulations were applicable to non-Jews in a majority Jewish community, as expressed in Lev 17:7-9; 10ff; 18:6-26; Ex 20:10f; 12:18f (Segal 1995:8).

15. This "rabbinic doctrine is derived from a sophisticated and theological formulation that some legal enactments were given before Sinai to all human beings". Various versions of such Noachide commandments exist, and the first proper or full formulation dates back to the third century CE. However, earlier, pre-Christian versions are found in e g Jubilees (where the function of these commandments are, however, expressed to seal the condemnation of Gentiles) and Sibylline Oracles, as well as in writings by Pseudo-Phocylides and Aristeas. Such commandments seem to include the prohibition of idolatry, promiscuity and violence (Segal 1995:8-12).

16. Segal points out that in such situations where the Jews lacked political power, this model avoided a potential "backlash" from the Gentile communities' accusations of "stealing their children" (1995:17). 
Noachian commandments, ${ }^{17}$ with no specific rules of Judaism in place, especially not circumcision" (Segal 1995:20). Paul argues that all people sin and are judged by the Law (e g Rom 1:18-3:20), and therefore that all people — Jews and Gentiles — need to "repent and enter the way through faith". As there are no "separate covenants" for Jews and Gentiles, ${ }^{18}$ both Jew and Gentile need to be "transformed by their faith in the risen, spiritual Christ". Gentile Christians are therefore to be treated as "righteous Gentiles"; not as "resident sojourners", but as "equals". Regarding his views on the practice of the Law and the salvation of the Gentiles, Paul's approach approximates other positions in Judaism. ${ }^{19}$ It stands to reason that Paul's expectations of his fellow believers in Christ entailed taking up a new identity which would prove particularly troublesome to most Jews.

Segal therefore argues that Paul's "basic assumption" in his letters is not a "critique of works centered righteousness", which Segal calls a concern "characteristic of a later time". Paul's primary concern is with "the process of transformation by faith that brings justification", a universal process for both Jewish and Gentiles converts to Christianity. In the process he distinguished between "fleshly and spiritual observances", or in Segal's words, between "ceremonial" and "moral" law. Segal agrees with Dunn that "works of the Law" denotes the effects of ceremonial laws in the community, but adds that it refers to ceremonial laws as such, as well: "Paul is saying that the special laws of Judaism are not relevant for salvation" (1995:23-24). The special or ceremonial Jewish laws are not nullified, but relativised by faith in Christ: they are now voluntary, "although he [Paul] concedes they may be practiced for the sake of church unity". ${ }^{20}$ It meant that " $[t]$ he effect of Paul's preaching and his vision of a new, unified Christian community was the destruction of the ritual distinction between Jew and Gentile within the Christian sect" (Segal 1995:27, emphasis in the original). Paul, Segal argues (1995:29), provides significant insight into the Jewish position(s) on universalism in the first century. Both Judaism and Christianity, under influence of the events of the Hellenistic period and the dominant cultural forces of the day, argued not just for universalism but also for toleration of differences within monotheistic religion.

\subsection{Paul, Christ and identity: New identity}

[T]he church is to find its identity and vocation by recognizing its role within the cosmic drama of God's reconciliation of the world to himself (Hays 1996:19).

Paul redefines identity in contending that when people are "left to their own devices, to themselves"; they lose their "true identity, their personhood" (Georgi 1992:97). In his letters,

17. Unlike the "apostolic decree" as presented by Luke (Ac 15:20,29; 21:25), which assumes the model of rules applicable to the sojourner (Segal 1995:13-20).

18. As e g Gaston (1987), Gager (1983) and, of course, Stendahl argue: for the Jews, on basis of the Law; for Christians on basis of Christ. Cf recently also Bockmuehl, n20 below.

19. Although his emphasis on "the centrality of faith, his insistence that all need transformation, and his specific language for flesh and spirit" are different from the positions of other Hellenistic Jewish writers (Segal 1995:23).

20. This would go some way towards addressing charges of "inconsistency" (Sanders) and "incoherency" (Räisänen) leveled against Paul's statements on the Law: although Paul operates according to the Noachian commandments-model, "he is willing to accept some of the rules of the sojourner if that will achieve peace and unity within his community of Christians" (Segal 1995:26-27). Bockmuehl (1995:100) contends that Paul attempted "to forge a united body of Jewish and Gentile Christians in a fellowship of equals, in which the former continue to live by the special laws and the latter merely by the Noachide laws". 
there are traces of a concerted effort to establish a new identity for the communities receiving his correspondence.

Paul claimed that the gospel shattered the consciousness of social distinctions, most especially that between the Jew and the Gentile. It evoked a vision of a new society in which the Christian participated by virtue of Christ. To be "in Christ" meant for Paul the acceptance of a new consciousness that transcended the social margins of his day (Kysar 1991:115).

Trobisch (1994:91) argues that Paul edited Romans, 1 and 2 Corinthians and Galatians with the specific purpose of the Jerusalem collection in mind. It is significant that one of the topics related to this goal was the issue of Christian identity, since "for the first time in literary history a Christian theologian defines what it means to be a Christian in contrast to being a Jew". 21

It can safely be said that identification with Christ was at the center of the new identity promoted by Paul. This identification was both soteriologically and ethically oriented and interacted with two dominant symbols, cross and resurrection ${ }^{22}$ (Lampe 1995:931-943), and variously expressed, not least of which with prepositional phrases with sun and even and Christ. Soteriologically the corporate aspect of both symbols would provide two invitations to identification while the ethical dimension includes the Pauline emphasis on "interhuman love and upbuilding instead of selfishness" as well as "a patient and joyful enduring of troubles". Lampe translates these notions into psychoanalytical terms, arguing that the difference between one who imitates and one who identifies with the model person, is that the latter not only displays similar behaviour but adopts the model person's motivations, goals and emotions, as well. This would require a "libido impulse" or affection between Christ and believers, and eventually leads to "a radical restructuring of the Ego by identification with Christ", initiated by the ritual identification process of baptism. ${ }^{23}$

[T] he early Christian talk about a newly created ego does not describe, mirror or represent an already existing reality. No, it creates this reality of a new ego, being information (informatio) in the real sense of the word - that is, a forming and creating word, and performative language. ... The entire realm of social relationships is based on words and information that create reality (Lampe 1995:940, emphasis in the original).

Paul participated in this identification in close interaction with the scriptures of Israel, which often provided the words and information, the vocabulary and content of the Pauline sense of identity.

Pauline advocacy regarding a new identity was closely connected to his vision of a new community, and the resultant new identity within such a community. ${ }^{24}$ "The justifying grace

21. However, it is questionable whether the terms "Christian theologian" and contrasting "Christian" and "Jew" are appropriate ways to refer to Paul's theological activities and his self-definition.

22. "The Christian finds identity there [the eschatological act of God in Jesus Christ] rather than in the cosmic reason, and that identity enables and requires participation in the eschatological cause of God" (Verhey 1983:119)

23. Paul's emphasis in Rom 6 and elsewhere on change in status, assumption of new roles, and recreating identity recalls notions of "rites of passage" or "initiation". The role of baptism in the identity of Christ believers and their identification with Christ deserves more sustained treatment and will not be addressed here but cf e g Engberg-Pedersen (1995a:502); Kysar (1991:74) "The society of the church was a single, seamless fabric by virtue of its shared baptism in Christ".

24. Georgi (1991:52ff) refers to "the corporate identity of Christ"; cf Hays (1996:32-36) for the "fundamental emphasis on community in Paul's thought". Martin (1994:117-140) questions the supposed individualist character of Hellenism. It is interesting to note how much of the original Pauline emphasis was retained in the eastern church: "In the Eastern church, the problem of the relation of faith to works has never had such a 
creates wise and reasonable, in a word good, praxis, in which personhood and the identity of persons is formed through relatedness and concern for others" (Georgi 1992:160). Acknowledgement of the strong communal sense in Paul's writings requires a reevaluation of the hitherto individualist emphasis in Pauline interpretation. In Lindbeck's language, Paul's appropriation of the scriptures of Israel was not primarily symbolic-expressive - about individualist self-consciousness — but cultural-linguistic — about community formation and sustenance. The point where Paul's concern with creating a new identity for the followers of Christ intersects with his concern that such community is community-related, is found in his appropriation of the Scriptures of Israel.

\section{Paul, Scripture and identity: Enscripturalising identity}

Both the exodus story as told by Paul and the manner in which Paul tells that story provide a paradigm for Christian identity and the continuous telling, retelling, and enacting of the Christian story (Keesmaat 1997:325, emphasis added).

An important concern in Paul's countenance of identity is in order at this stage, and it has two sides: Paul's letters are manifest testimony to the outcomes of the propagation of a particular identity - be it intercultural — obviously promulgated in the communities where his influence was felt. A second, if often neglected, aspect is that Paul's sense of identity was largely connected to the scriptures which he took as his foundational documents, and through which a proper, dynamic and participatory, enscripturalising identity was established. "Paul was struggling with the question of what it meant to serve God in Jesus Christ and was doing so in fundamental continuity with the traditions and Scriptures of his people, Israel" (Keesmaat 1997:324). This does not discount the role of the Christ-event, death and resurrection in Paul's advocacy of new identity, but stresses Paul's insistence on rereading Scripture, in light of Christ. Paul did not employ a christocentric hermeneutic but rather what can be called an ecclesiocentric hermeneutic (Hays 1989) or, even better, an embodying hermeneutic (Meeks 1986). Paul read the scriptures of Israel as prefigurement of, and with the aim towards establishing, communities of faith. Paul's hermeneutic of embodiment provided important strands for the communal webs under construction, wherein he participated and which he often supervised.

It goes without saying that Paul's letters and identity can be investigated from various perspectives and starting points. Not only because this study is about enscripturalised identity, but since identity in Paul is largely dependent on his relationship with the scriptures of Israel, ${ }^{25}$ it seems proper to emphasise Paul's use of the scriptures of Israel in his construction of identity. Even where the debate on Paul is still conducted in terminology reminiscent of FC Baur, as recently again popularised by for example JGD Dunn - namely that Paul is opposing Jewish exclusivism as manifested in nationalism - the significance of his use of the scriptures of Israel is not disputed. For example, Dunn argues that Paul countered (some) Jews who were too strongly emphasising their "distinctiveness" from Gentiles on the basis of Israel's status as the "chosen people" of God. They invested their identity "too far in the presumption

central position. In the East, Christians regard Paul as a saint, a mystic and a martyr. As to his theology, his image of the church as the body of Christ was more important than his doctrine of justification" (Dahl 1977:20; emphasis added).

25. Hafemann (1993:679) suggests that many questions regarding the interpretation of Paul's letters — especially the issues of the role of the Torah and the significance of justification for Paul's view of redemptive history "can only be solved by a renewed study of Paul's use and understanding of the OT". 
that Israel was set apart from 'the nations"” (1990:172). "In Dunn's analysis, the objects of Paul's critique were "nationalistic presumption" and "ethnic restrictiveness" neither of which were, in Paul's view, a proper interpretation of the Jewish Scriptures” (Barclay 1996:202, emphasis added). Whether one agrees then with the Baur-Dunn template for understanding Paul, it is nevertheless clear that it was in the Torah and especially in Deuteronomy where the Jewish distinctiveness was traditionally inscribed, in covenantal terminology. The claim that God accepted the Jewish people was the starting point for their obedience to God.

Bearing in mind that Paul's identity was largely informed by his Jewishness (Gal 1:13-14; Phil 3:5-6) and especially by his acknowledgement of his alignment with the Pharisaic movement -- and thus, by his incorporation into a textual community - Paul's identity was not only inscribed but also prescribed by the scriptures of Israel. Especially as far the halakot were concerned, the scriptures of Israel demanded particular actions but moreover also a certain lifestyle. ${ }^{26}$ Such a lifestyle was intimately connected to the creation of a certain worldview accompanied by a specific consciousness of character or identity. This identity would, however, change through and as reflected in his radically different appropriation of the scriptures of Israel. Two brief references to two different passages in Paul's letters will have to be suffice in underscoring both Paul's conscious engagement with the Scriptures of Israel and his particular hermeneutical style in this regard.

\subsection{Scripture, hermeneutics and an enscripturalising community (2 Cor 3:6)}

This story of biblical interpretation begins in the Bible, where the prophets rework the exodus narratives, the New Testament interprets the "Old" (the construction of these categories was itself a major interpretive event), and Paul offers allusive remarks about the letter and the spirit that are to influence subsequent patristic principles of exegesis (Schwartz 1990:4).

Paul's use of the Scriptures of Israel has of late again come up for discussion and 2 Cor 3:6 is not infrequently referred to, especially when read from a modern dichotomous notion of literal and allegorical, as Paul's definite reflection on his hermeneutical theory. ${ }^{28}$ The passage

26. Cf Tomson's argument (1990) on the similarities between the Pauline letters and Jewish halakot.

27. Cf Hafemann (1992:31-49) for a valuable summary of some recent attempts to interpret this passage; recently (1998:246-257) he himself opted to read this text according a prophecy-fulfillment scheme. Another novel way of interpreting this text, if not from direct quotation then indeed by allusion, is found in Von Harnack (1995:47) who claimed that "Paul refuses indirectly (pneu,matoj ouv gra,mmatoj [spirit not letter]), a religion of the book, that is of the Old Testament". As far as novel readings of 2 Cor 3:6 are concerned, cf Jobling (1993:455-456) who insists on reading it psychoanalytically, concluding: "So my reading is at odds with Paul - or, shall we say, on the Jewish as opposed to the Christian side".

28. 2 Cor 3 has in any case been understood as a hermeneutical key to the understanding of Scripture in the early Christian church (Forde 1983:243). Cf Chau (1995) who traces the letter/spirit contrast in the hermeneutics of the early Christian church through to Luther. Houston (1996:166-167) stops just short of advocating 2 Cor 3:6 as the basis for distinguishing "different and deeper levels" of meaning in our contemporary exegetical efforts. Quite different, but equally insistent is Stockhausen (1993:143-164) that Paul is "a man with methods", and she argues that 2 Cor 3 illustrates these methods in a fine way as "an exegetically centered passage", not because it has "a specific hermeneutical intent". Unfortunately, Stockhausen restricts her discussion to Paul's methods only, whereas 2 Cor 3 seems to point beyond that to the goal of Pauline hermeneutics as well. Cf also Blank (1991:275-278) on this text providing "the most profoundest dimensions and ultimate presuppositions of 'the hermeneutical business"'. Cf also Müller (1989:37); Steinmetz (1980:28-30), citing three conclusions from Paul's so-called distinction between "the "story-book" or narrative level of the Bible and the deeper theological meaning or spiritual significance implicit within it": narratives do not necessarily — even if they 
is seen to exemplify the hermeneutical stance of Paul, being his fundamental reflection about understanding Scripture "in Christ" (Koch (1986:331-341). There are two ways of reading Scripture, which are not only different from, but also fundamentally opposed to, one another (Decock 1993:275). The difference is not so much in content as in effect: the one kills, while the other gives life. It is reading, therefore, not only as human receptivity, but also as human activity.

There is, however, no unanimous support for a hermeneutical reading of 2 Cor 3 since it has been read since the time of Augustine and prominently later also by Luther to refer to the distinction between law and grace, exemplifying the contrast between the "letter which kills" and the "spirit which gives life" (Ebeling 1993:131,138-140). ${ }^{29}$ Westerholm (1984:229-248) argues at length that in 2 Cor 3 Paul uses the letter-spirit antithesis to stress the nature of his ethics and not his hermeneutics. ${ }^{30}$ Gra,mma (letter) and pneu/ma (Spirit) do not refer to different modalities of reading Scripture, as in literal and symbolical, but to the demands of Scripture. In a later study, Westerholm (1988:212-216) continues his argument that "letter" and "Spirit" refer to "two different ways of rendering service". ${ }^{31}$ When he compares this text with Rom 2:27 and 7:6, Westerholm concludes that these texts all agree: Letter and Spirit refer to "the essence of service under the two covenants" - and perhaps even more, as suggested in the title of Westerholm's 1988 book, to Israel's law and the Church's faith.

Hooker (1981:303) is of the opinion that one should read 2 Cor 3 in the first place as being concerned with the "ministry of Moses", with reference to the contrast between the ministries of Moses and Paul, or old covenant and the new - and these are respectively described as gra,mma and pneu/ma. This opposition of "letter" and "Spirit" does not refer to the contrast Law-Gospel, or Moses-Christ but concerns Paul's view on the role of Scripture. Paul refers to the reading of both the old covenant and Moses — and as in so many contexts these two may very well be synonyms. Scripture is not to be "abolished', neither according to contemporary Jewish belief, nor according to Paul (Rom 3:31). For Paul Scripture is his first witness to Christ, and the role of Scripture is fundamental to both Moses and Paul in their ministries.

In his "intertextual" study of Pauline interpretation of the scriptures of Israel, Hays $(1989: 122-153)^{32}$ first accounts for such divergent lines of interpretation of this passage from Käsemann to Westerholm — and subsequently illustrates that this passage is "neither a

claim to - reflect factuality; Paul needed to address the relationship between Israel and the Church and their respective "traditions"; and, not all Scriptural narratives are "edifying as they stand".

29. However, Augustine is willing to accept that in a secondary way this passage can be read with relation to interpretive positions, but he fails to argue this in detail. It seems, however, that unlike the Origenist position of literal and allegorical senses, Augustine derived the hermeneutical value of the letter-spirit distinction from the ability to reread the "Old Testament" in a christological, and thus "life-giving" way. The theological and the hermeneutical therefore coincided in Augustine's appropriation of letter and spirit. For references to other opposition of 2 Cor 3 as Pauline reflection on interpretive practice, cf Chau (1995:2-3); Hays (1989:123-124).

30. And supported by Bandstra (1990:259). Further support for the "ethical" reading of this passage comes from Tuckett (1991:311). Interestingly, the approaches of these authors seem to exhibit somewhat of a neoLutheran inclination in their approach to Paul.

31. The reference to the "veil" when Jews read the Bible, 2 Cor 3:14-15, is seen as the concealment of the "transitory nature of the old covenant" which explains their failure to perceive the abolishment of that covenant in Jesus Christ (Westerholm 1988:213 n36).

32. Hays discusses at length the "lifting of the veil" of Moses (2 Cor 3:12-4:4), a passage not without importance for the discussion here, but which for lack of space cannot be included in this study. Cf also Hafemann (1992:31-49) for a discussion of Paul's interpretation of Moses' veil and the meaning of katarge,w (to abolish; make powerless, idle, ineffective; to bring to an end; not, however, to fade away) in the context of Ex 34:2935; and the comprehensive study by Belleville (1991) on the Moses-Doxa tradition. 
practical discussion of how to do exegesis nor a theological treatise on the problem of continuity and discontinuity between the testaments". However, this passage is on the other hand not merely about an ethical principle or two, as " $[\mathrm{t}]$ he meaning of Scripture is enacted in the Christian community, and only those who participate in the enactment can understand the text. Consequently, the transformation of the community is not only the presupposition but also the result and proof of true interpretation". Hays argues that 2 Cor 3 is more concerned than other passages such as Rom 15:4 and 1 Cor 10:11, with the issue of "continuity" or "discontinuity" in the relationship between Scripture and the new Christian communities, initially, and later between the two "testaments". He understands 2 Cor 3:6 within its broader context (3:1-4:6) as part of Paul's defense of his apostolic authority. ${ }^{33}$ Hays views Paul's references to Jer 38:33 (God writing upon the heart) and Ezek 36:26 (fleshy hearts replacing ones of stone) as determinative of Paul's salient point: "in the new covenant incarnation eclipses inscription", or, the message of Jesus Christ will subsume "itself into the life of the community, embodied without remainder". This allows Hays to accommodate ethics ${ }^{34}$ besides hermeneutics in the letter/spirit contrast: "true reading produces the transformation of the readers. Consequently, there can be no dichotomy between hermeneutics and ethics" (Hays 1993:45; cf 1989:152).

According to Hays, the contrast in letter/spirit refers not to the contrast between literal or material as opposed to the allegorical or spiritual, but rather to inscribed as opposed to living or embodied. In the ministry of the new covenant, the changing of people's lives matters more than a ministry of labouring over words. However, with the emphasis on the Spirit, it should be noted that Paul's rejection concerns the gra,mma, not the grafh. Paul's letter/spirit contrast is not primarily, according to Hays, about hermeneutics but does indicate "a radically new orientation toward Israel's Scripture", underlining Paul's ecclesiocentric hermeneutic.

The meaning of Scripture is enacted in the Christian community, and only those who participate in the enactment can understand the text. Consequently, the transformation of the community is not only the presupposition but also the result and proof of true interpretation (1989:152; cf Hafemann 1998:255).

This text indicates Paul's conscious choice for an ecclesiocentric hermeneutics, providing an important aspect in the transformation of a scriptural, indeed, a scripturalising community and fostering a new identity through a new reading. In short, Paul's hermeneutic is essentially an embodied hermeneutic.

\subsection{Freedom, theological and hermeneutical (Gal 4:21-5:1)}

This anti-structure of the real family of God is continued with logical consistency in the allegory of Hagar and Sarah, which eventually leads to the freedom motif being announced as the topos of the last two chapters (5-6, cf 4:31). Paul's strategy is to develop new self-understanding in the minds of his readers (Lategan 1992:263).

Paul's embodied hermeneutic is characterised by interpretive freedom, which interacts with his emphasis on theological freedom and which jointly contributes to the new selfunderstanding Paul is keen to engender. The character of Pauline hermeneutics and to some

33. Cf recently Hafemann's (1998:246-257) claim on 2 Cor 2:14-7:6, 10:1-13:10 being Paul's most sustained defense of his apostolic ministry; Brown (1998:271-285) on Paul's defense in terms of the apocalyptic defined scheme of "power-in-weakness".

34. Cf Boyarin's (1994:97) remark on "hermeneutics as ethics"; Fowl and Jones (1991); Meeks (1986). 
extent also the new identity ${ }^{35}$ he advocates are in sharp focus in Gal 4:21-5:1, generally described by biblical commentators as an allegory of the (first) two wives - and their sons of Abraham. The ostensible purpose of the allegory is to offer the "Christians" in Galatia an offer which they cannot refuse, an option for either slavery or freedom, an option repeated in Gal 5:1 (Malina 1978:68), and an option which describes the character their lives will assume.

Gal 4:31-5:1 brings the argumentative section of Galatians to a close and the allegory summarises and enforces Paul's theological position. ${ }^{36}$ This is a theological position characterised by freedom, both freedom in approach (his reworking, reinterpretation or revisioning of his religious belief and Scripture) and in content (based on the death and resurrection of Christ) - two aspects which stand in a reciprocal relationship. By insisting on the importance of faith in Christ, Paul relinquishes the primacy of the Jewish law and shows that his reconstructed theological position was not a superficial adaptation of what he believed before his Damascus-road experience. Indeed, as Boyarin (1994:152-157) shows, Paul essentially succeeds in the "allegorization of the Torah". This is clearly already a major theological shift, before even evaluating the nature and content of Paul's reconstructed theology, or comparing that with his previously held position.

It is important to note that Paul considers the employment of an allegory (hermeneutical freedom) as the best way to prove his (theological) point: True freedom follows from faith in Christ, whereas the law leads to enslavement. ${ }^{37}$ For Paul, hermeneutical and theological freedom informs one another. His free and creative hermeneutics allows for a radical reinterpretation of Scripture, as much as his freedom in reconstructing his theological position gives rise to the use of hermeneutical freedom in rereading Scripture. ${ }^{38}$ As much as a different theological stance ${ }^{39}$ would have led his free hermeneutics to different conclusions, a hermeneutic tied to midrashic middoth (for example) would not have allowed Paul to argue for belief in Christ as the new covenant.

35. Cf Boyarin's (1994:156-157; cf 1993:69-70) arguments on the political nature of Paul's allegory. Boyarin sees the Hagar and Sarah allegory as "perhaps the biblical text that most explicitly thematized exclusion". This is in line with Boyarin's argument that Paul saw in "human sameness" the "only possibility for human equality" as "[d]ifference was the threat". Paul wanted to "allegorise" Jewish difference, indeed all human difference out of existence: allegory is therefore "essentially, paradigmatically, imbricated in these cultural politics". Contra Boyarin, Volf contends that equality does not equate with sameness (1996:66).

36. In rhetorical terms, it serves as the recapitulatio; for a discussion of the rhetorical structure, cf Smit (1986:113-144) and Betz (1979). The difference between these two scholars — the former identifies Galatians as "deliberative" rhetoric, while Betz sees it as "judicial" — would not affect the rhetorical position of this section of Galatians.

37. It is in Paul's writings where the "first production of the critique of the irrationality of the rationalized" (Hinkelammert 1997:46-47) can be found, with his insistent criticism of the law: The law does not save upon its fulfillment; and as a matter of fact, sin is committed in fulfilling the law. As in medieval thinking: Fiat injustitia, pereat mundus (the law must be fulfilled even if the world must perish). "Christian freedom returns therefore, in the sense pronounced by Paul, as a freedom that is sovereign before the law" (Hinkelammert 1997:47).

38. Paul's theological point of departure is important: Hays nevertheless notes that the "conventional Jewish interpretation" of the Hagar-Sarah story in Jubilees is also allegorical (1989:113).

39. For an important discussion on Paul's theology of freedom, cf Barrett (1985:17-52) who refers e g to Paul's "controversial" and "critical" theology, in which he felt free to "modify and expand ... conventional formulas". Barrett argues that Paul's theology of freedom was characterised by three aspects: freedom, obligation and "Christ alone". Therefore, "Paul was free to think; yet under an obligation to an authority greater than his own, willing even to contemplate the possibility that he might himself diverge from the true gospel and so incur his own anathema (1.8; cf 1 Cor 9.27)" (1985:52). 
To discuss 2 Cor 3:6 and Gal 4:21-5:1 in close proximity might raise expectations of concluding a Pauline proclivity for matters allegorical, surpassing the literal in hermeneutical and theological value. This is, however, not the argument I want to put forward. Rather I want to conclude that Paul operated a conscious hermeneutic, that this hermeneutic was constituted by (content) and through (method) freedom, and that this hermeneutic had as its aim a new identity. Keesmaat's statement (1997:324) on the dynamic and creative use of the exodus tradition in Galatians can be generalised: "[T]hat tradition is both appropriated and reinterpreted by Paul so that the identity of this community is not the same identity of those who participated in the first exodus event". To put it briefly, in his discussion of the new identity of believers, Paul displays an embodied hermeneutic characterised by freedom.

\section{Religion, Scripture and identity on the eve of the Third Millennium}

The development of that African identity, from a religious point of view, is related to the Word of God by which people are changed (Pobee 1993:393).

As South African church history shows, the problem of difference lies at the heart of the inability of human beings to live together in justice, freedom and peace (Ackermann 1998:13).

It is ironic that with the anti-Apartheid struggle which was so closely involved with matters related to social identity, identity in the new South Africa has become more diffuse and variegated than it ever was. ${ }^{40}$ And the reality of the statement "if you do not have an identity, you will be like a drop of mist in an unformed, undefined cloud" (Marty 1996:28 quoting Gasset), is nowhere more true than in this country. Although the South African case is ironic, it is probably not difficult to understand and is due to many reasons: a new emphasis on a non-racial society; radical changes to traditional societal structure and arrangements; an openness to the wider world leading to a questioning of traditional life-style and values; and so on. An important aspect of any study of identity today is the role and influence of globalisation on people's lives, prompting Pobee to say: "There is no way Africans can search for their identity in a corner" (1993:387). ${ }^{41}$

And more specific to this discussion, it will certainly be interesting and important to investigate if and how the diminished public role attributed to religion, ${ }^{42}$ contributes to the growing identity crisis in South Africa. It is generally accepted that the religious movements in general, and the Christian church in particular, played a vital role in the political change and the transition to a multiracial government in South Africa. The role of the church and her leaders was clearly seen in their advocacy of human rights, reconciliation and non-violence.

40. Cf Said on the understandable urge for "nationalism" and nationalistic identity among those emerging from oppression and marginalisation, "a long deferred and denied identity needs to come out into the open and take its place among other human identities". He warns also about it danger in limiting "human horizons without either intellectual or, I would argue, political warrant". Nationalism as "the philosophy of identity made into a collectively organized passion" remains only a first step after liberation (1991:17).

41. Not only is the neo-capitalist theory and practices of a global market economy religiously inscribed and legitimised, but the empire reappears as "absolute and closed", where "power dictates what reality will be like" (Hinkelammert 1997:38-42). Any discussion of identity in Africa therefore has to reckon with the powerful influence of globalisation as well as its accompanying religious dimensions.

42. However, recently the SA government and president Mbeki in particular have been issuing strong appeals to the churches to address what is considered inappropriately high levels of moral problems, and to take a special interest in restoring the moral health of the country. 
But with many churches and their leaders increasingly retreating from the public arena on own initiative and otherwise, the new public role of religion might indeed contribute to the fluidity of the margins of identity in post-Apartheid South Africa.

It is generally agreed that religion plays an important role "in shaping human consciousness" (Novak 1996:100-101) - "[r]eligion, whatever else it may be or do, provides an overarching interpreting and legitimating frame of reference for the socially constructed worlds that humans inhabit" (Lindbeck 1984:27 n10) - one aspect of which is religion's tendency to contribute to human identity: "Religions help people know who they are" (Marty 1996:15), or "[r]eligion defines how groups of people see both themselves and the other, or outsider" (Neusner 1996:32). The bottom-line is, "[r]eligious beliefs and convictions, then, can have a tremendous influence on how we, as individuals and a nation, react to new situations, new ideas, and new technologies" (Haas 1996:186). ${ }^{43}$ Religion has the power therefore, to make the concrete into something general and encompassing: "to name and treat as real the otherwise random confluence, in belief and behavior, of isolated groups and people" (Neusner 1996:42-43). ${ }^{44}$

Turning to Scripture and the role of the Pauline letters regarding matters of identity, Boyarin (1994:32, cf 9-10,290 n10) has criticised what he perceives as Paul's advocacy of cultural accommodation in his letters. Boyarin argues that such accommodation is functional only when matters often called "cultural" are deemed peripheral and mutable, but not when the supposedly cultural are integrated with the religious conscience. In short, Boyarin "rightly suggests that the very 'tolerance' of cultural difference turns out to be subtly intolerant of those for whom the maintenance of their cultural traditions cannot be a matter of taste, but is the very core of their identity" (Barclay 1996:212). This issue is of importance for doing theology in Africa and has given rise in the past to misunderstanding and even conflict. ${ }^{45}$ Should African customs be required to simply change or adapt in order to facilitate the transferring of certain (Western culturally endowed) theological concerns?

[I]t is better that we create possibilities for community on some common ground than that we tear the fabric of societies whose cultural threads are already too interwoven to be simply unraveled. A cautious use of our Pauline heritage could equip us to undertake that long and difficult search for a polity which both respects ineradicable difference and enables meaningful community (Barclay 1996:214).

As far as the role of the Bible and the identity of communities subscribing to it are concerned, more investigation is needed on the nature and mutuality of the relationship. Is the Bible calling forth such communities with their particular sense of character, or do communities with an already defined and shared sense of identity pledge allegiance to related biblical values?

43. At times it is expressed even more radical: "One's religion is the essence of one's identity, even in the Western world, which emphasizes individual worth, merit, and responsibility" (Sanders 1999:35).

44. The point is not that it is only in Africa where identity is entangled with religion; to the contrary, as Bosch (1995:43, quoting Lübbe) claimed: "No nonreligious society has ever been found anywhere in the world, and there is no culture that is not profoundly influenced by religious premises".

45. Cf Pobee: "Given pluralism as a background for the search for African identities the search must entail guiding people into positive and creative acceptance of religious pluralism without which there can be no peaceful future" (1993:392). This also raises the issue of multiscripturality. Pobee (1993:393) adds, "In my view the Word of God is not only the Christian's Bible. Other religions also have God's word. But as Christian, I also believe that Word of God and God's Spirit work to renew the person, including their identities". 
The moral norms of society always interact with statements of the churches and religious communities, especially if these are constitutive of people's identity. In a culture historically influenced by the Christian church and faith, norms and values interpreted from the Bible belong to the whole community of people, not only the church. Thus the interpretation of the Bible, often unconsciously, serves in both the secular and ecclesiastical exercise of power (Nissinen 1998:3-4; cf Carroll R 1995:193).

Reflecting on the role of the Bible in post-Apartheid South Africa, there are certainly signs that the Bible is still capable of influencing people. The Bible will have a formative role on people if scriptural communities are to exist or come into existence that are powerful enough to influence the public ethos in the new South Africa (Smit 1991:51-67). Such a role for Scripture will depend on the "plausibility structures" operative in communities: Is the Bible still making sense today and are people not only purchasing but also "buying into" the Bible? Although the broad Christian community in South Africa might not (yet) be that, a "cognitive minority" can maintain their unpopular ideas only if it has a strong community structure (Sider 1977:167-168). So in South Africa one is to expect that there will be a reciprocal relationship between, on the one hand, Scripture influencing communities, and on the other, communities embodying biblically inspired values in society.

Paul's call for identification with Christ poses a number of challenges to church and society today, relating as much perhaps to identity as to ethics. So for example, the resurrection of Christ would encourage churches to refrain from adopting a cynical and martyred attitude and rather carry out their mission in (with) the world. Society is challenged to "realise and respect" its limits, "to mature collectively by willingly scaling back our present exuberant life styles" (Lampe 1995:936). "Against the traffic of our hedonistic culture" with its "almost addictive media dependency" Paul offers an option to identify with Christ instead of with the stronger or more powerful (Lampe 1995:942).

Even more significant than the content of Paul's call for identification with Christ for believing communities today, is the way in which it issues forth from his engagement with the scriptures of Israel. Paul's hermeneutic of embodiment warrants our involvement with Scripture, which includes the retelling as well as the transformation of the "story" of Israel, and Paul's telling of that story. Such an endeavour would require us to discern how Paul's letters address us today, as "[t]he power of a story to create a world and shape reality for people is clear". Much can be learnt from Paul's involvement with the scriptures of Israel, realising the detrimental effects of many traditional categories of Western Christianity. Pauline hermeneutics can lead the way in showing how to dispose of a radical anthropocentric view of the world, of an extreme individualism, and how to critique the church's option for entrenchment in the face of increasing plurality (cf Keesmaat 1997:325-328).

\section{Conclusion: Christian identity and Scripture}

The new identity is about developing a new anthropology. This is a task for all regions of the world - not just Africa. The old anthropologies have collapsed. The Greek anthropology like biblical anthropology and traditional African anthropologies are not exactly live options in this new age of science and global village; Communist-Socialist ideology too is collapsing. Africa searches for a new identity alongside other continents, and peoples by inter alia searching for a new anthropology (Pobee 1993:388).

The post-Apartheid rainbow nation of South African is still in its infancy, desperately trying to stand up out of a crawl in order to start walking. Given the multicultural diversity of 
South Africa, as exemplified in its eleven official languages, the advice of Gasset even as it emerges from another context should be taken to heart: "With the peoples of Central and South America, Spain has a past in common, common language, common race; and yet it does not form with them one nation. Why not? There is one thing lacking which, we know, is the essential: a common future" (1951:133). The claim is not that Scripture poses the ultimate unifying factor for the South African society. However, with the Bible in South Africa still largely perceived as a significant and meaningful text - a foundational document (Scroggs 1995) with a life-giving quality (Camp 1993:161-163) - it is at least irresponsible to ignore its involvement in matters related to religious and social identity. Biblical scholars, too, carry their share of the responsibility to research and teach the Bible while interacting with people's lives on various levels of human existence. This entails necessarily that the relationship between identity formation, maintenance and transformation and the Bible cannot be ignored. $^{46}$

As much as the search for identity is the search to adequately describe what being human in a certain context is all about - that is, for anthropology - it is not incomprehensible that life on the eve of the third millennium gives rise to such a quest. People find themselves floundering in the sea of a technocratic, industrialised and totalitarian global village (cf Bosch 1995:2-3). However, in deliberating on the current and possible future role of the Bible in matters related to African identity, one needs to avoid various kinds of "missionary paternalism" (Pobee 1993:393), as well as a missionary paternalism in reverse, or more aptly, affirmative paternalism. If, as is so often argued (cf Bediako 1996:1-11; Pobee 1993:394), Africa is fast becoming the center of gravity for Christianity, and if is so that the Christian Bible is generally highly rated and used in Africa, this might halt or even reverse a decanonising trend in Western Christianity. A return to Scripture (Ochs 1993) might be on the cards for the new millennium, and the contribution of Paul's letters would not only be to offer identification with Christ but more especially a particular hermeneutic, built upon and characterised by freedom.

46. From a feminist perspective, Lee (1998:260-161) has recently suggested that a "sense of presence, participation and transformation [of human lives] can be gained from the sacred text viewed as icon". 


\section{BIBLIOGRAPHY}

Achtemeier, E 1980. Creative Preaching. Finding the Words. Abingdon Preacher's Library, ed. WD Thompson. Nashville: Abingdon.

Ackermann, DM 1998. Becoming Fully Human: An Ethic of Relationship in Difference and Otherness. Journal of Theology for Southern Africa 102: 13-27.

Bandstra, AJ 1990. Scholia: Notes and Comments for the Minister: Paul and the Law: Some Recent Developments and an Extraordinary Book. Calvin Theological Journal 25(2):249-261.

Barclay, JMG 1996. "Neither Jew nor Greek": Multiculturalism and the New Perspective on Paul. In Ethnicity and the Bible, ed. MG Brett, 197-214. Leiden: Brill.

Barrett, CK 1985. Freedom and Obligation. A Study of the Epistle to the Galatians. Philadelphia: Westminster.

Bediako, K 1996. Understanding African Theology in the 20th Century. Bulletin For Contextual Theology in Southern Africa \& Africa 3(2):1-11. (Previously published in Themelios 20(1):14-20)

Betz, HD 1979. Galatians. A Commentary on Paul's Letter to the Churches in Galatia. Hermeneia. Philadelphia: Fortress.

Beyer, P 1994. Religion and Globalisation. Theory, Culture \& Society. London: SAGE.

Bij de Vaate, AJ and JW Van Henten. 1996. Jewish or Non-Jewish? Some Remarks on the Identification of Jewish Inscriptions from Asia Minor. Bibliotheca Orientalis 53 (1-2): 16-28.

Blank, J 1991. "According to the Scriptures": The New Testament Origins and Structure of Theological Hermeneutics. In Paradigm Change in Theology. A Symposium for the Future, eds. H Küng and D Tracy, 261-282. Trans. M Köhl. Cross Road: New York.

Bockmuehl, M 1995. The Noachide Commandments and New Testament Ethics. With Special Reference to Acts 15 and Pauline Halakah. Revue Biblique 102(1): 72-101.

Bosch, DJ 1995. Believing in the Future. Toward a Missiology of Western Culture. Christian Mission and Modern Culture. Valley Forge: Trinity.

Boyarin, D 1993. Was Paul an "Anti-Semite"? A Reading of Galatians 3-4. USQR 47(1-2): 47-81.

Boyarin, D 1994. A Radical Jew. Paul and the Politics of Identity. Critical Studies in Jewish Literature, Culture, and Society, vol 1. Berkeley: University of California Press.

Brown, AR 1998. The Gospel Takes Place. Paul's Theology of Power-in-Weakness in 2 Corinthians. Interpretation 52(3): 271-285.

Camp, CV 1993. Feminist Theological Hermeneutics: Canon and Christian Identity. In ed. E Schüssler Fiorenza, Searching the Scriptures. Volume 1: A Feminist Introduction, 154-171. London: SCM.

Carroll RMD. 1995. The Bible and the Religious Identity of the Maya of Guatemala at the Conquest and Today: Considerations and Challenges for the Nonindigenous. In The Bible in Ethics. The Second Sheffield Colloquium, eds. J Rogerson, M Davies and MD Carroll R, 193-212. JSOT Supplement Series vol 207. Sheffield: Sheffield Academic Press.

Chau, WS 1995. The Letter and the Spirit. A History of Interpretation from Origen to Luther. American University Studies, Series VII: Theology and Religion, vol 167. 
New York: Peter Lang.

Dahl, NA 1977. Studies in Paul. Theology for the Early Christian Mission. Minneapolis: Augsburg.

Davies, WD. 1980. Paul and Palestinian Judaism: Some Rabbinic Elements in Pauline Theology. 4th ed. Philadelphia: Fortress.

Decock, PB 1993. The Reading of Sacred Texts in the Context of Early Christianity. Neotestamentica 27(2): 263-282.

Donaldson, TL 1994. "The Gospel that I Proclaim among the Gentiles" (Gal 2.2): Universalistic or Israel-Centred? In Gospel in Paul. Studies on Corinthians, Galatians and Romans for Richard N Longenecker, 166-193. JSNT Supplement Series, vol 108. Sheffield: Sheffield Academic Press.

Dunn, JDG 1990. Jesus, Paul and the Law. Studies in Mark and Galatians. Louisville: WJK.

Ebeling, G. 1993. The Beginnings of Luther's Hermeneutics. Lutheran Quarterly 7(2-3): 129-158.

Engberg-Pedersen, T 1995a. Galatians in Romans 5-8 and Paul's Construction of the Identity of Christ Believers. In eds. T Fornberg and D Hellholm, 477-506.

Engberg-Pedersen, T 1995b. Introduction. In Paul in His Hellenistic Context, ed. T Engberg-Pedersen, xiii-xxiv. Minneapolis: Fortress.

Evans, CA and JA Sanders, eds. 1993. Paul and the Scriptures of Israel. JSNT Supplement Series, vol 83. (SSEJC 1). Sheffield: Sheffield Academic Press.

Feldman, LH 1986. How Much Hellenism in Jewish Palestine? Hebrew Union College Annual 57: 83-111.

Fischer, JA 1996. Interpreting the Bible. A Simple Introduction. Mahwah: Paulist.

Forde, DO 1983. Law and Gospel in Luther's Hermeneutic. Interpretation 37(3): 240-252.

Fornberg, T and D Hellholm (eds.). 1995. Texts and Contexts. Biblical Texts in their

Textual and Situational Contexts. Essays in Honor of Lars Hartman. Oslo: Scandinavian University Press.

Fowl, SE and Jones, LG 1991. Reading in Communion. Scripture and Ethics in Christian Life. Grand Rapids: Eerdmans.

Gager, J 1983. The Origins of Anti-Semitism: Attitudes towards Judaism in Pagan and Christian Antiquity. New York: Oxford University Press.

Gasset, JO 1951. The Revolt of the Masses. London: Unwin.

Gaston, L 1987. Paul and the Torah. Vancouver: University of British Columbia Press.

Georgi, D 1991. Theocracy in Paul's Praxis and Theology. Trans. DE Green. Minneapolis: Fortress.

Georgi, D 1992. Remembering the Poor: The History of Paul's Collection for Jerusalem. Trans. I Racz. Nashville: Abingdon.

Goldenberg, R 1997. The Nations that Know Thee not. Ancient Jewish Attitudes towards Other Religions. Biblical Seminar, vol 52. Sheffield: Sheffield Academic Press.

Grabbe, LL 1994. Judaism from Cyrus to Hadrian. London: SCM.

Green, WS and J Neusner. 1996. The Religion Factor. An Introduction to How Religion Matters. Louisville: WJK.

Haas, PJ 1996. Religion and Ethics. In eds. WS Green and J Neusner, 186-197.

Hafemann, SJ 1992. The Glory and the Veil of Moses in 2 Cor 3:7-14: An Example of Paul's Contextual Exegesis of the OT - a Proposal. Horizons in Biblical Theology 
14(1): 31-49.

Hafemann, SJ 1993. Paul and His Interpreters. In Dictionary of Paul and his Letters, eds. GF Hawthorne, RP Martin and DG Reid, 666-679. Downers Grove: IVP.

Hafemann, SJ 1998. Paul's Use of the Old Testament in 2 Corinthians. Interpretation 52(3): 246-257.

Hays, RB 1989. Echoes of Scripture in the Letters of Paul. New Haven: Yale University Press.

Hays, RB 1993. Echoes of Scripture in the Letters of Paul: Abstract. In eds. CA Evans and JA Sanders, 42-6.

Hays, RB 1996. The Moral Vision of the New Testament. A Contemporary Introduction to New Testament Ethics. San Francisco: HarperSanFrancisco.

Hinkelammert, FJ 1997. Liberation Theology in the Economic and Social Context of Latin America: Economy and Theology, or the irrationality of the Rationalized. In Liberation Theologies, Postmodernity, and the Americas, eds. D Batstone et al, 2552. London \& New York: Routledge.

Hooker, MD 1981. Beyond the Things that are Written? St Paul's Use of Scripture. NTS 27: 295-309.

Horsley, RA 1995. Innovation in Search of Reorientation. New Testament Studies Rediscovering Its Subject Matter. JAAR 62(4): 1127-1166.

Houston, JM 1996. Toward a Biblical Spirituality. In The Act of Bible Reading. A MultiDisciplinary Approach to Biblical Interpretation, ed. E Dyck, 148-173. Downers Grove: IVP.

Howell, jr, DN 1993. Pauline Thought in the History of Interpretation. Bibliotheca Sacra 150(599): 303-326.

Jobling, D 1993. Globalization in Biblical Studies/Biblical Studies in Globalization. Biblical Interpretation 1(1): 96-110.

Keesmaat, SC 1997. Paul and His Story: Exodus and Tradition in Galatians. In Early Christian Interpretation of the Scriptures of Israel. Investigations and Proposals, eds. CA Evans and JA Sanders, 300-333. JSNT Supplement Series, vol 148. (SSEJC 5). Sheffield: Sheffield Academic Press.

Koch, D 1986. Die Schrift als Zeuge des Evangeliums. Untersuchungen zur Verwendung und zum Verständnis der Schrift bei Paulus. Beiträge zur historische Theologie, vol 69, ed. J Wallman. Tübingen: JCB Mohr (Paul Siebeck).

Kysar, R 1991. Called to Care. Biblical Images for Social Ministry. Minneapolis: Fortress.

Lampe, P 1995. Identification with Christ. A Psychological View of Pauline Theology. In eds. T Fornberg and D Hellholm, 930-943.

Lategan, BC 1992. The Argumentative Situation of Galatians. Neotestamentica 26(2): 257-277.

Lee, DA 1998. Touching the Sacred Text: The Bible as Icon in Feminist Reading. Pacifica 11(3): 249-264.

Lieu, J, North, J and Rajak, T 1992. Introduction. In The Jews among Pagans and Christians, eds. J Lieu, J North and T Rajak, 1992: 1-8. London \& New York: Routledge.

Lindbeck, GA 1984. The Nature of Doctrine. Religion and Theology in a Postliberal Age. Philadelphia: Westminster.

Lindbeck, GA 1989. Scripture, Consensus, and Community. In Biblical Interpretation in Crisis: The Ratzinger Conference on Bible and Church, ed. RJ Neuhaus, 74-101. 
Encounter Series, vol 9. Grand Rpaids: Eerdmans.

Malina, BJ 1978. Freedom: A Theological Enquiry into the Dimensions of a Symbol. BTB 8: $62-76$.

Martin, LH 1994. The Anti-Individualistic Ideology of Hellenistic Culture. Numen 41(2): 117-140.

Marty, ME 1996. Religion and Nationality. In eds. WS Green and J Neusner, 15-31.

Matlock, RB 1998. Almost Cultural Studies? Reflections on the "New Perspective" on Paul. In Biblical Studies/Cultural Studies. The Third Sheffield Colloquium, eds. JC Exum and SD Moore, 433-459. JSOTSS vol 266; Gender, Culture, Theory vol 7. Sheffield: Sheffield Academic Press.

Meeks, WA 1985. Breaking Away: Three New Testament Pictures of Christianity's Separation from the Jewish Communities. In "To See Ourselves as Others See Us": Christians, Jews, "Others" in Late Antiquity, eds. J Neusner and ES Frerichs, 93115. Chico: Scholars.

Meeks, WA 1986. A Hermeneutics of Social Embodiment. HTR 79(1-3): 176-186.

Müller, P 1989. Tradition und Geist bei Paulus. Theologische Berichte 18: 31-60.

Murray, R 1982. Jews, Hebrews and Christians. Some Needed Distinctions. Novum Testamentum 24(3): 194-208.

Neusner, J 1996. Being Israel: Religion and Ethnicity in Judaism. In eds. WS Green and J Neusner, 32-43.

Nissinen, M 1998. Homoeroticism in the Biblical World. A Historical Perspective. Minneapolis: Fortress.

Novak, M 1996. Religion and Political Economy. In eds. WS Green and J Neusner, 99-116.

Ochs, P, ed. 1993. The Return to Scripture in Judaims and Christianity. Essays in Postcritical Scriptural Interpretation. Theological Inquiries. Mahwah: Paulist.

Pobee, JS 1993. Africa in Search of Identity. In The Ecumenical Movement Tomorrow. Suggestions for Approaches and Alternatives, eds. M Reuver, F Solms and G Huizer, 387-398. Kampen, Geneva: Kok, WCC.

Said, EW 1991. Identity, Authority and Freedom: The Potentate and the Traveller. (TB Davie Memorial Lecture.) Cape Town: UCT.

Sanders, JA 1999. Intertextuality and Dialogue. BTB 29(1): 35-44.

Schwartz, RM 1990. Introduction: On Biblical Criticism. In The Book and the Text. The Bible and Literary Theory, ed. RM Schwartz, 1-15. London: Basil Blackwell.

Scroggs, R 1995. The Bible as Foundational Document. Interpretation 49(1): 17-30.

Segal, AF 1990. Paul the Convert. The Apostolate and Apostacy of Saul the Pharisee. New Haven: Yale University Press.

Segal, AF 1995. Universalism in Judaism and Christianity. In ed. T Engberg-Pedersen, 129.

Sider, RJ 1977. Rich Christians in an Age of Hunger. A Biblical Study. London: Hodder and Stoughton.

Smit, J 1986. Redactie in de Brief aan de Galaten. Rhetorische Analyse van Gal. 4,12-6,18. Tijdschrift voor Theologie 26: 113-144.

Smit, DJ 1991. The Bible and Ethos in a New South Africa. Scriptura 37:51-67.

Smith, JKA 1997. The Closing of the Book: Pentecostals, Evangelicals, and the Sacred Writings. JPT 11: 49-71. 
Steinmetz, DC 1980. The Superiority of Pre-Critical Exegesis. Theology Today 37: 27-38.

Stiver, DR 1996. The Philosophy of Religious Language. Sign, Symbol, and Story. Oxford: Blackwell.

Stock, B 1983. The Implications of Literacy. Written Language and Models of Interpretation in the Eleventh and Twelfth Centuries. Princeton: Princeton University Press.

Stockhausen, CK 1993. 2 Corinthians 3 and the Principles of Pauline Exegesis. In eds. CA Evans and JA Sanders, 143-164.

Tomson, PJ 1990. Paul and the Jewish Law: Halakah in the Letters of the Apostle to the Gentiles. Compendia Rerum Iudaicarum Ad Novum Testamentum, Section III. Jewish Traditions in Early Christian Literature, vol 1. Assen/Maastrich, Minneapolis: Van Gorcum, Fortress.

Trobisch, D 1994. Paul's Letter Collection: Tracing the Origins. Minneapolis: Fortress.

Verhey, A 1984. The Great Reversal. Ethics and the New Testament. Grand Rapids: Eerdmans.

Volf, M 1996. Exclusion and Embrace. A Theological Exploration of Identity, Otherness, and Reconciliation. Nashville: Abingdon.

Von Harnack, A 1995. The Old Testament in the Pauline Letters and in the Pauline Churches. In Understanding Paul's Ethics: Twentieth-Century Approaches, ed. BS Rosner, 27-49. Grand Rapids, Carlisle: Eerdmans, Paternoster.

Walters, G, Martin, SW and Cochrane, JR 1997. Constructing a Language of Religion in Public Life. Summary Analysis of the Proceedings of the Preparatory ME99 Academic Workshop held in Cape Town from 30 September to 2 October, 1998. Journal of Theology for Southern Africa 103: 64-87.

Westerholm, S 1984. Letter and Spirit: The Foundation of Pauline Ethics. NTS 30: 229-48.

Westerholm, S 1988. Israel's Law and the Church's Faith. Grand Rapids: Eerdmans. 